\title{
Commentary
}

\section{Counting Replication Origins to Measure Growth of Pathogens}

\author{
Godefroid Charbon ${ }^{1}{ }^{(1)}$, Maria Schei Haugan ${ }^{2}$, Niels Frimodt-Møller ${ }^{3}$ and \\ Anders Lobner-Olesen $1, * \mathbb{D}$ \\ 1 Department of Biology, University of Copenhagen, Ole Maaløes vej 5, 2200 Copenhagen N, Denmark; \\ godefroid.charbon@bio.ku.dk \\ 2 Department of Medical Microbiology, St. Olavs Hospital, Trondheim University Hospital, 7006 Trondheim, \\ Norway; maria.schei.haugan@stolav.no \\ 3 Department of Clinical Microbiology, Rigshospitalet, 2100 Copenhagen, Denmark; \\ niels.frimodt-moeller@regionh.dk \\ * Correspondence: lobner@bio.ku.dk; Tel.: +45-3532-2068
}

Received: 2 April 2020; Accepted: 5 May 2020; Published: 8 May 2020

check for updates

\begin{abstract}
For the past several decades, the success of bacterial strains in infecting their host has been essentially ascribed to the presence of canonical virulence genes. While it is unclear how much growth rate impacts the outcome of an infection, it is long known that the efficacy of the most commonly used antibiotics is correlated to growth. This applies especially to $\beta$-lactams, whose efficacy is nearly abolished when cells grow very slowly. It is therefore reasonable to assume that a niche or genetic dependent change in growth rate could contribute to the variability in the outcome of antibiotic therapy. However, little is known about the growth rate of pathogens or their pathotypes in their host.
\end{abstract}

Keywords: growth rate; pathogen; in situ; antibiotics; DNA

\section{Introduction}

Recently, efforts have been made to understand the growth dynamics of bacteria in situ. Classically, bacterial population dynamics are observed by viable cell counting using colony forming units (CFUs). This gives a good indication of the size of the bacterial population at the time of sampling. Although, because a change in bacterial load results from both cell growth and cell death, it fails to measure how fast bacteria are growing (Figure 1).

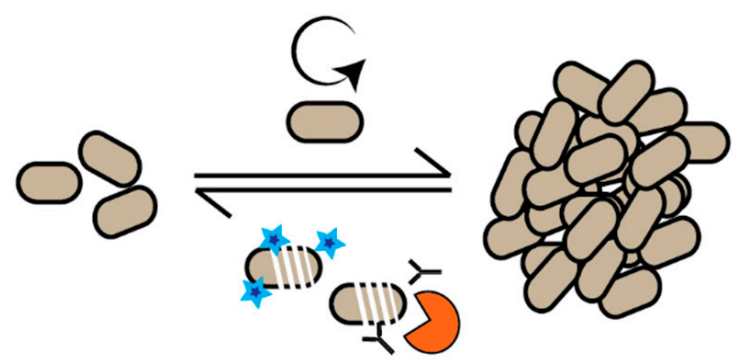

Figure 1. In situ population dynamics. The size of a bacterial population is determined by how fast individual cells grow and how fast the cells are killed by antibiotics or immune system defense mechanisms.

Simply put, the same CFU count can be obtained from a population of cells growing fast with a high death rate, as from a population of cells growing slowly with a low death rate. In test tube 
experiments, growth is usually measured by change in optical density. This is obviously not feasible in in-host setups, and death rate attributed to immune system response or antibiotics is not taken into account.

\section{DNA Replication as a Growth Marker}

Lately, several methods have been applied to infer the in situ growth rate of bacteria [1-8]. One of these methods takes advantage of the coupling of DNA replication with growth rate. In Escherichia coli and other bacteria, initiation of DNA replication is linked to growth rate changed by nutrient availability [9,10]. In E. coli, it takes a minimum of $\sim 60 \mathrm{~min}$ to finish a cell cycle. The bidirectional DNA duplication starts from the origin of replication (oriC) and finishes at the terminus (ter), a minimum of $40 \mathrm{~min}$ later (C period). Subsequently, it takes $\sim 20 \mathrm{~min}$ for the cell to divide (D period). Thus, the oriC copy number is increased for a certain amount of time before the ter copy number increases. In cells growing very slowly, DNA is replicated in a small proportion of the cell cycle, while during fast growth, cells are born with overlapping rounds of DNA replication. The upshot is that the ratio of oriC to ter reflects the growth rate of a bacterium. Invariably, in a population of actively replicating cells, oriC/ter is above 1 (Figure 2).

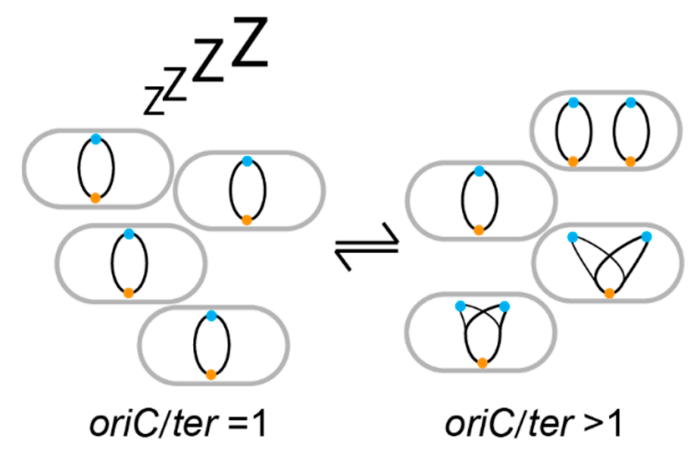

Figure 2. Origin of replication/terminus (oriC/ter) ratio as a measure of growth rate. Non-growing cells (left) possess fully replicated chromosomes with one oriC (blue ball) and one ter (orange ball). During the DNA duplication period of growing cells (right), there are more oriC than ter. Thus, the oriC/ter ratio of the population is above 1 .

Already, this information becomes valuable to distinguish growing cells from non-growing cells; non-growing cells do not replicate their DNA, thus oriC/ter is equal to one. Cells growing faster than it takes to finish a cell cycle $(\mathrm{C}+\mathrm{D})$ are born with chromosomes in the process of being replicated, thus multiple oriC per one ter. For example, a population of E. coli growing in rich media or in situ can have eight oriC in a single cell and an oriC/ter ratio of about four. The faster the cells grow the more oriC per ter. This remarkable correlation has long been acknowledged, but only recently has it been used as a proxy to measure growth of pathogens in their host. This has been done by quantitative PCR amplification of oriC and ter [11-13], marker frequency analysis by whole genome sequencing [3,4,14-16], or direct microscopic visualization of fluorescently labeled oriC and ter in live cells [11,13], all of which will be referred to as marker frequency analysis (MFA) in the text. The value of the information obtained from such techniques is made apparent in some examples from recent studies that will be discussed below.

\section{Dynamics in Specific Niches}

The first example of this application comes from the study of uropathogenic E. coli (UPEC) causing urinary tract infections. Human urine was long thought to be too toxic to accommodate any kind of growth. Yet, growth of UPEC has been measured to be extremely fast (faster or similar to growth in Lysogeny broth rich medium) [4]. This shows that the bacterium not only thrives in the urinary tract, but also implies that fast growth could be mechanistically required for bacterial maintenance in niches 
with fast fluidic discharge. Using MFA for measuring growth, a similar mechanism was proposed for Staphylococcus aureus growing in the nasal cavity [2]. There are also a significant number of bacteria that cannot be grown in synthetic media, their existence only revealed by DNA sequencing. Here, growth rate derived from MFA has been valuable to obtain very basic data on their growth in situ [14].

\section{Dynamics During an Infection Process}

In the second example, focus is placed on the population dynamics during infection: Are there few bacteria at the infection site because they grow slowly or is it because they are cleared by the immune system despite fast growth? (Figure 1). Common to the few studies made so far, is that there is a not a clear correlation between the bacterial load (CFU per gram) and the growth rate measured at the site of infection. This is exemplified in an analysis of the gut microbiome in an infant developing necrotizing enterocolitis, revealing that the load of Clostridium species was very low despite rapid bacterial growth [14]. In another example following the dynamics of a mouse peritoneal infection over time, the load of E. coli at the primary site of infection increased and reached a plateau [11]. This apparent plateau in bacterial load is made up of both slowly growing and non-growing cells kept in check by the host immune system. A low load of E. coli was also found in the bloodstream; however, the growth rate of the bacteria in the blood mirrored the one found in the peritoneal cavity throughout the infection. This supports the concept that the bacteria found in the bloodstream are not establishing themselves but represent a mere spill-over from the site of infection. The conclusion from this study was that the mouse immune system is presumably capable of better clearance of E. coli in the bloodstream than in the peritoneum.

\section{Dynamics During Antibiotic Therapy}

Finally, knowledge about in situ bacterial growth could be used to select appropriate antibiotics or predict their efficacy. For example, this is seen when analyzing the efficacy of antibiotics in eradicating an E. coli infection from the mouse peritoneum [13]. Before antibiotic treatment, the bacterial population was made up of non-growing and slowly growing cells. Treatment with ceftriaxone, a $\beta$-lactam drug, preferentially eliminated growing cells, consistent with what is known about this class of antibiotics $[17,18]$ (Figure 3). This type of analysis is now expanded to analyze E. coli during human urinary tract infection therapy [12].

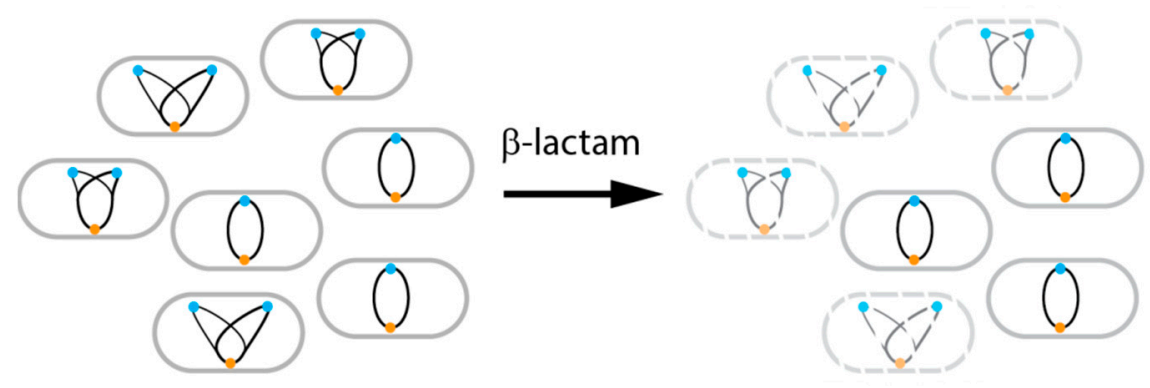

Figure 3. Measure of growth rate as read out for antibiotic efficacy. Selective action of $\beta$-lactams on actively growing cells (more than one oriC per ter) is represented.

\section{Concluding Remarks}

While it is established that a variety of E. coli can cause human infection, it is now also clear that the pathogens do not invariably grow at the same pace. The use of MFA to measure bacterial growth dynamics during infection provides a potential for future patient-bacterium specific antibiotic treatment regimens. 
Author Contributions: Conceptualization, G.C., A.L.-O., M.S.H. and N.F.-M., Writing-original draft preparation, G.C. Writing-review and editing, G.C., A.L.-O., M.S.H. and N.F.-M. Funding acquisition, A.L.-O. and N.F.-M. All authors have read and agreed to the published version of the manuscript.

Funding: This research was funded by grants from the Novo Challenge program (Center for Peptide-Based Antibiotics: Cepan), and from the Novo Tandem program.

Conflicts of Interest: The authors declare no conflicts of interest.

\section{References}

1. Riglar, D.T.; Richmond, D.L.; Potvin-Trottier, L.; Verdegaal, A.A.; Naydich, A.D.; Bakshi, S.; Leoncini, E.; Lyon, L.G.; Paulsson, J.; Silver, P.A. Bacterial variability in the mammalian gut captured by a single-cell synthetic oscillator. Nat. Commun. 2019, 10, 4665. [CrossRef] [PubMed]

2. Szafranska, A.K.; Junker, V.; Steglich, M.; Nubel, U. Rapid cell division of Staphylococcus aureus during colonization of the human nose. BMC Genom. 2019, 20, 229. [CrossRef] [PubMed]

3. Korem, T.; Zeevi, D.; Suez, J.; Weinberger, A.; Avnit-Sagi, T.; Pompan-Lotan, M.; Matot, E.; Jona, G.; Harmelin, A.; Cohen, N.; et al. Growth dynamics of gut microbiota in health and disease inferred from single metagenomic samples. Science 2015, 349, 1101-1106. [CrossRef] [PubMed]

4. Forsyth, V.S.; Armbruster, C.E.; Smith, S.N.; Pirani, A.; Springman, A.C.; Walters, M.S.; Nielubowicz, G.R.; Himpsl, S.D.; Snitkin, E.S.; Mobley, H.L.T. Rapid Growth of Uropathogenic Escherichia coli during Human Urinary Tract Infection. MBio 2018, 9, e00186-18. [CrossRef] [PubMed]

5. Myhrvold, C.; Kotula, J.W.; Hicks, W.M.; Conway, N.J.; Silver, P.A. A distributed cell division counter reveals growth dynamics in the gut microbiota. Nat. Commun. 2015, 6, 10039. [CrossRef] [PubMed]

6. Abel, S.; Abel zur Wiesch, P.; Chang, H.H.; Davis, B.M.; Lipsitch, M.; Waldor, M.K. Sequence tag-based analysis of microbial population dynamics. Nat. Methods 2015, 12, 223-226. [CrossRef] [PubMed]

7. Rang, C.U.; Licht, T.R.; Midtvedt, T.; Conway, P.L.; Chao, L.; Krogfelt, K.A.; Cohen, P.S.; Molin, S. Estimation of growth rates of Escherichia coli BJ4 in streptomycin-treated and previously germfree mice by In Situ rRNA hybridization. Clin. Diagn. Lab. Immunol. 1999, 6, 434-436. [CrossRef] [PubMed]

8. Yang, L.; Haagensen, J.A.; Jelsbak, L.; Johansen, H.K.; Sternberg, C.; Hoiby, N.; Molin, S. In Situ growth rates and biofilm development of Pseudomonas aeruginosa populations in chronic lung infections. J. Bacteriol. 2008, 190, 2767-2776. [CrossRef] [PubMed]

9. Cooper, S.; Helmstetter, C.E. Chromosome replication and the division cycle of Escherichia coli B/r. J. Mol. Biol. 1968, 31, 519-540. [CrossRef]

10. Donachie, W.D. Relationship between cell size and time of initiation of DNA replication. Nature 1968, 219, 1077-1079. [CrossRef] [PubMed]

11. Haugan, M.S.; Charbon, G.; Frimodt-Moller, N.; Lobner-Olesen, A. Chromosome replication as a measure of bacterial growth rate during Escherichia coli infection in the mouse peritonitis model. Sci. Rep. 2018, 8, 14961. [CrossRef] [PubMed]

12. Haugan, M.S.; Hertz, F.B.; Charbon, G.; Sahin, B.; Lobner-Olesen, A.; Frimodt-Moller, N. Growth Rate of Escherichia coli During Human Urinary Tract Infection: Implications for Antibiotic Effect. Antibiotics (Basel) 2019, 8, 92. [CrossRef] [PubMed]

13. Haugan, M.S.; Lobner-Olesen, A.; Frimodt-Moller, N. Comparative Activity of Ceftriaxone, Ciprofloxacin, and Gentamicin as a Function of Bacterial Growth Rate Probed by Escherichia coli Chromosome Replication in the Mouse Peritonitis Model. Antimicrob. Agents Chemother. 2019, 63, e02133-18. [CrossRef] [PubMed]

14. Olm, M.R.; Brown, C.T.; Brooks, B.; Firek, B.; Baker, R.; Burstein, D.; Soenjoyo, K.; Thomas, B.C.; Morowitz, M.; Banfield, J.F. Identical bacterial populations colonize premature infant gut, skin, and oral microbiomes and exhibit different In Situ growth rates. Genome Res. 2017, 27, 601-612. [CrossRef] [PubMed]

15. Brown, C.T.; Olm, M.R.; Thomas, B.C.; Banfield, J.F. Measurement of bacterial replication rates in microbial communities. Nat. Biotechnol. 2016, 34, 1256-1263. [CrossRef] [PubMed]

16. Olm, M.R.; Bhattacharya, N.; Crits-Christoph, A.; Firek, B.A.; Baker, R.; Song, Y.S.; Morowitz, M.J.; Banfield, J.F. Necrotizing enterocolitis is preceded by increased gut bacterial replication, Klebsiella, and fimbriae-encoding bacteria. Sci. Adv. 2019, 5, eaax5727. [CrossRef] [PubMed] 
17. Tuomanen, E.; Cozens, R.; Tosch, W.; Zak, O.; Tomasz, A. The rate of killing of Escherichia coli by beta-lactam antibiotics is strictly proportional to the rate of bacterial growth. J. Gen. Microbiol. 1986, 132, 1297-1304. [CrossRef] [PubMed]

18. Lee, A.J.; Wang, S.; Meredith, H.R.; Zhuang, B.; Dai, Z.; You, L. Robust, linear correlations between growth rates and beta-lactam-mediated lysis rates. Proc. Natl. Acad. Sci. USA 2018, 115, 4069-4074. [CrossRef] [PubMed]

(C) 2020 by the authors. Licensee MDPI, Basel, Switzerland. This article is an open access article distributed under the terms and conditions of the Creative Commons Attribution (CC BY) license (http://creativecommons.org/licenses/by/4.0/). 